AVANT, Vol. XI, No. 2

ISSN: 2082-6710 avant.edu.pl/en

DOI: 10.26913/avant.2020.02.03

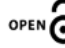

\title{
Contextualism in Context: Interview with Michael Williams
}

\author{
Luca Corti \\ University of Porto \\ MLAG - Mind, Language, and Action Group (Institute of Philosophy, U.Porto) \\ luca.corti@hotmail.de \\ Diana Couto \\ University of Barcelona \\ BIAP/LOGOS Research Group in Analytic Philosophy \\ MLAG - Mind, Language, and Action Group (Institute of Philosophy, U.Porto) \\ dpcouto@ub.edu
}

Received 4 October 2019; accepted 5 October 2019; published 10 January 2020

"Contextualism" is usually taken as the name for a very general view that can be found in different areas: from semantics to epistemology, from philosophy of language to philosophy of action. According to contextualism the role of context is necessary for an utterance, knowledge claim or action to have meaning or be intelligible. In philosophy of language, the idea is that what an utterance expresses depends on the context, which therefore has a role in determining its truth-conditions. One of the most renowned "radical contextualists", Charles Travis writes: "words may have any of many semantics, compatibly with what they mean. Words in fact vary their semantics from one speaking of them to another" (2008, p. 123). Epistemic contextualism, on the other hand, is the view that certain features of the context affect the standards that a subject $S$ must meet in order for $S^{\prime}$ beliefs to count as knowledge (or, alternatively, for a sentence attributing knowledge to $S$ to be true). Knowledge attributions are context-sensitive.

Like the other forms of contextualism, epistemic contextualism comes in various flavors. A lot depends on how one defines the notion of context. However, the position came into much focus as a potential response to the problem of skepticism.

Michael Williams, British philosopher, Fellow of the American Academy of Arts and Sciences since 2007, and Krieger-Eisenhower Professor at Johns Hopkins University, can be considered as one of the founding fathers of these views, and one of the most prominent opponents of the so-called "epistemological realism". In his books Unnatural Doubts (1991) and Problems of Knowledge (2001) he carried out a "theoretical diagnosis" of skepticism and put forward a groundbreaking response to it by suggesting that the skeptic is committed to an unsustainable form of epistemological realism which, therefore, should be rejected. This realism, roughly, is 
not meant to deny that we have knowledge of an objective, mind-independent reality, but rather that the entities of the epistemological inquiry are context-invariant. Alongside with other renowned contemporary epistemologists such as Stewart Cohen and Keith DeRose, Williams' work has been path-breaking for "contextualism", especially when it comes to his positions on skepticism that have been prompted discussion ever since he first advanced them.

In addition to his work on epistemology, Williams' is also attentive to topics in the history of philosophy, and in particular the historical development of the skeptical tradition, as well as the philosophy of language and Wittgenstein. With regard to the former, he has argued that the modern and contemporary skeptical arguments differ significantly from those developed in the ancient philosophy. With regard to the latter, he has been concerned with two issues: the distinction between "contextualism" and "relativism" and the so-called new wave approach to Wittgensteinian "hinge Epistemology".

The resonance William's work has with fields other than epistemology such as the ones just mentioned are quite surprising. Inspired by the work of Wittgenstein, Ayer, and Sellars, his chiseled arguments have been carefully discussed in important intellectual circles. He undoubtedly deserves a prominent place in the history of contemporary philosophy.

This interview was carried out on 13 December 2018 as Michael Williams was in Porto for a meeting of the Contextualism Network organised by the MLAG - Mind, Language, and Action Research Group (Institute of Philosophy of the University of Porto). We would like to thank him for his willingness to reply to our questions.

LuCa CORTI \& Diana Couto: To begin with, we would like to ask you about your philosophical and biographical path. Can you tell us something about the main stages of your intellectual development and its most important turning points (also in terms of both your interests in certain topics and the answers you gave to the most relevant questions)?

MiChael WiLliams: I have a somewhat strange background. I crossed from one side of the street to the other, so to speak. I was an undergraduate at Oxford in the 1960s and eventually fell under the spell of A. J. Ayer. I met him through a class he used to give called "Informal Instruction", where each week they read a paper or a chapter of a book. It wasn't a lecture course, there was just open discussion. Of course, it was Freddy Ayer's show. The question, in a way, was always: "Who is the second cleverest person in the room?".

I was a poor boy from the provinces. At first I sat there wondering "What am I doing here?", but I eventually began to take part. There were a lot of graduate students there too. I remember one time, I think we were reading something on Quine, and somebody in the group asked a question and Ayer said: "Hmm. Good question. One for you I think, Williams".

After I finished my undergraduate degree I stayed as a postdoctoral student under Ayer's supervision for one year. But I wasn't enjoying Oxford really very much, because I've been there as an undergraduate and staying on in the same place as a post-graduate was too much the 
same. I saw a little advertisement on the back of the College entrance door about a scheme being run by the University of Chicago. It was for a young graduate student from Oxford to come over for one academic year and do some part-time teaching. I thought: "That seems interesting!". So I applied and I got the job.

When I came to America I was very impressed by Chicago, by the graduate students there and, in a way, by the American graduate education. It was much more organized than Oxford. The American graduate education was more structured: there were courses and an oral exam on your thesis topic. I thought I would apply to graduate school in America, so I did it and applied to a couple of places. I thought "If I get in, I will stay; if I don't, I will go back to Oxford".

I ended up going to Princeton, and this was quite a change from Ayer who was a paradigm logical empiricist. In Princeton I fell under the spell of Richard Rorty when he was writing Philosophy and the Mirror of Nature (1979). I don't believe people look much at the Preface of that book, but he mentions two people as having read it in manuscript, and I'm one of them. So I was very close to him, and of course it turned me around.

I've been a critic of the epistemological tradition ever since, and I feel I know it from the inside, having initially studied with Ayer. My first undergraduate tutor at Oxford, John Foster, had also been very close to Ayer. And he remained something like a Berkeleyan idealist until the end of his life. I was one of his first pupils. Through him, partly I became involved with Ayer. But then, Rorty was just charisma: his seminars were really quite extraordinary. His ability was to go to the heart of a philosophical issue and say "This is what is going on here". So I have never regretted that change. I have never regretted leaving Oxford.

\section{LuCA CORTI \& DiAna COUTO: Richard Rorty, one of the most influential philosophers of the century, was your PhD supervisor in Princeton. Did his philosophy have a signifi- cant impact on your work?}

MiCHAEL WiLliams: Yes, very much, although I'm not a slavish disciple of Rorty. What I did get from him, and which I still think exemplifies my own work on skepticism in a way that makes it quite unusual, is that I don't just look at it from the perspective of the contemporary literature. I have thought about its history and written about the contrast between ancient and modern skepticism and also why Descartes is an historical turning point. I have always retained that desire for an historical perspective which Rorty had.

\section{LuCA CORTI \& DiAna COUTO: Apart from Rorty, did Sellars also have an impact on your work? What do you find so inspiring in his thought?}

Michael WiLliams: My first book Groundless Belief (1977) was very influenced by Sellars, but by Sellars as filtered through Rorty. I was never a student of Sellars. In fact, I only met him once in my life when I was Assistant Professor at Yale. Sellars was invited to give a talk there and all he wanted after his talk was to have some drinks and a good dinner. Surprisingly, the only people who would go to dinner with him were myself and another young woman 
philosopher of science who later became Dean at Harvard. So I met Sellars just that time, but I never discussed philosophy with him.

\section{LuCA CORTI \& Diana Couto: Why were some philosophical problems (such as skepti- cism) more attractive to you than others?}

Michael Williams: I don't know. I think that probably goes back to the people with whom I studied most as an undergraduate. You know why problems attract you. I was drawn to epistemology and never to moral philosophy or ethics. I had to take some courses as an undergraduate because of some final papers, but I think I can truthfully say I have never in my career written a single paper which could be thought to have the remotest connection to the moral philosophy. To use the Kantian phrase, I was drawn to theoretical philosophy, particularly to epistemology, but also later to philosophy of language and, in a somewhat skeptical way, to metaphysics (why do people feel the need to have it? I'm just not sure about the reason, but it certainly has always been so). I have never really been even remotely tempted to work in any other aspect of philosophy.

Something I think I came to through Rorty (but also through Sellars) is the historical perspective. I have never thought that one could treat epistemology as a kind of self-standing subspecialty, in the way some people do today. I don't believe there are clear lines between epistemology, philosophy of language, philosophy of mind, and metaphysics. Sellars' essay that had the most influence on me early was of course "Empiricism and The Philosophy of Mind" (1956). But note the title: it's not called "Empiricism and the Theory of Knowledge", even though it's to a large degree about the theory of knowledge (that's one of its main topics). Sellars thought from day one that theories of knowledge were always heavily influenced by other views that people had about meaning and the mind, if not their metaphysical inclinations. I have always thought that was right.

I really worry about the way epistemology is pursued in the contemporary journal literature. There has been a move - which is partly influenced not by intellectual issues, but by the incentive structure of the profession - towards an ever-narrower specialization on the part of graduate students, and a proliferation of specialized journals. And I don't think you can do good philosophy that way.

So one reason I admire Charles Travis' work is that he does philosophy in a way I think you should do it. He has been writing important things in papers that have impact in epistemology, in philosophy of language, in philosophy of mind... I think that is the right way to go. I have probably been a bit more focused on epistemology, but even so, it hooks up with other things that I do. And I have some views about philosophy of language and menta-semantics, which I've combined with my work in epistemology. 


\section{LuCA CORTI \& Diana COUTO: Do you think there are perennial questions/problems} (such as skepticism) in philosophy?

Michael WiLliams: Yes and no. Think of skepticism for instance: it is certainly a longlasting tradition, but I think the questions undergo significant change. You can find affinities, but I think it is a mistake to think that exactly the same problems are confronted in exactly the same form at all times. I do believe that in the case of skepticism Descartes marks a break. I think skepticism in its Cartesian form (particularly the external world problem) is not in the end fully detachable from Cartesian metaphysics: since metaphysics is not the background to ancient Greek skepticism, they don't get the external world problem in its fully radical fault as we find it in Descartes. They don't even have that notion of the external world. "External" really means "external to the Cartesian mind". The Greek skeptics talk about things around us,

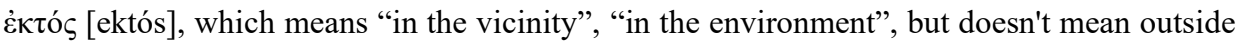
the mind. I was very influenced by Myles Burnyeat's paper on Idealism and Greek Philosophy (1982), but I've tried to add some detailed texture of my own. I don't fully accept Burnyeat's account of what the difference consists in. I have some quite detailed views about exactly what the difference is. One reason I like to combine systematic philosophy with some historical self-consciousness is that it helps to know how problems evolved because that tells you how they ought to be addressed now.

LUCA CORTI \& DIANA COUTO: In your 2001 book Problems of Knowledge you distinguish between "theoretical diagnosis" as opposed to "therapeutic diagnosis" (which tries to show that some problems, and in particular skeptical problems) are not even intelligible, and to "constructive theory" which tries to answer the question on their own terms. Can you say something about that distinction? In particular: are these methods mutually exclusive?

Michael Williams: Yes. I think this distinction is a bit problematic. The notion of "theoretical diagnosis" is problematic in two directions. My thought was this: skepticism is often represented as a paradox or a problem that arises through reflection on the ordinary concept of knowledge - or our ordinary conceptual justification, or our ordinary everyday epistemic practices. In Unnatural Doubts I claimed that this is a very important strength. Skepticism has to be - as I put there - "an intuitive problem". By that I didn't mean just that the skeptical arguments seem plausible at first sight - that seemed to be what Pritchard said. I meant that it must be genuinely intuitive, in the sense that it really must arise out of reflection on our everyday epistemic practice: it can't be an artifact of a controversial theorization of those practices. So the aim of "theoretical diagnosis" is to make the case that it is in fact an artifact of unacknowledged theoretical commitments. But the reason there was a need for diagnosis is that it doesn't always look like this: the arguments can be presented in a way that hides the fact that these controversial presuppositions have been made. My thought therefore was: you need to show that when you have really tried to follow the arguments through, there is more to the argument than is explicitly stated. That's the "diagnostic" aspect. 
But on the other side, I called it "theoretical" diagnosis because at the time (I'm not as sure about this as I was) I wanted to distinguish this kind of diagnostic project from a rather facile claim that skepticism makes no sense, or is incoherent. I don't think Austin himself was guilty of this, but in the post-Austinian phase of ordinary language philosophy there was some tendency to find things meaningless and too easy to direct the way. I thought that can't be quite right: even going back to Ayer's formulation of the skeptical argument one sees that it can't be meaningless. For if you buy the argument, you can already see how it opens up space for theoretical alternatives - or different ways that you would then respond to it. And that could hardly be so if it made no sense. So I preferred the idea of theoretical diagnosis, to stress that the question is not meaningless but it's not innocent either. In other words: you can't get to the problem just by reflecting on our ordinary use of words like 'knowledge', 'reasonable', 'justified'. You needed more than that: you needed some more general views that would not perhaps fully acknowledge... That was the thought. I wanted to stress skepticism as a problem that is perhaps internal to a certain theoretical research program rather than one that just arises by reflection on everyday practice. But I didn't want to say it was meaningless.

There's a way in which diagnosis as I understood it doesn't mean a knock down refutation. It's not that I'm attempting a nuclear strike on the skeptic. As I put it in Unnatural Doubts, we don't have to impose a Carthaginian peace. But perhaps we can argue that some of these problems are in a way past their sell-by-date, and we can now understand why it is that discussion of them has settled into grooves from which it seems unable to escape. It's not because the problem is impossibly hard, but because it's been phrased in a way that is not mandatory. In that sense my approach is very close in spirit to what John McDowell says: it's sufficient to show the problem is not forced on you, that there are other ways of thinking about the same phenomena so to say (the phenomenon of finding ourselves knowledgeable or not), which make perfectly good sense of our everyday practices without, as it were, generating a skeptical conundrum. And that's enough, and you shouldn't want more. That was my thought then, and that's my thought now. I'm not particularly original in this. Even Robert Nozick says philosophy shouldn't be quite so coercive. You can offer another way of thinking about these matters.

\section{LuCa CORTI \& DiAna COUTO: Do you think there are other philosophical ways to ad- dress these questions? Are you a pluralist about philosophical methods or do you think that there is one approach to be preferred?}

Michael Williams: I do think that in the end philosophy aims at a kind of self-understanding. But this idea can be understood in various ways. Austin once described his method as "linguistic phenomenology". I've come around to the view that that's a good way of thinking and indeed has something in common with what is called phenomenology in the continental tradition. But phenomenology is not an easy endeavour at all. First of all - and this is where it combines with the diagnostic method - somehow we're tempted into kinds of theorizing that make it difficult to see the way these everyday and deeply human things actually work. It's not something like "Oh, I just need to introspect and I'll see exactly how our concept of knowledge works." It's not like that. You have in fact to both look at the phenomenon (and what matters about it) and, at the same time, you have to combine that with a diagnostic project 
that takes away things that distort your vision. Notice that it is not a scientific project either. It is, if anything, an essay and interpretation - a hermeneutic project, if you like.

The way I now conceive philosophy can be called an HDP conception of philosophy: it's 'Hermeneutic', 'Diagnostic' and 'Phenomenological'. That's what I think I'm doing in my work. I must admit, I probably went over to the dark side. Unusually for an analytic trained philosopher I taught a yearlong graduate seminar on Heidegger's Being and Time (1962) a year or so ago (I did it jointly with the continentally-trained colleagues; I wasn't alone in the room). But I found it a very useful exercise. Many people think Heidegger is very obscure, and the writing is very difficult. But it is not actually difficult in any random page of Michael Dummett! There's plenty of analytic philosophy which isn't that easy to follow first time around. I suppose I got that from Rorty too. He was very broad minded about what counts as philosophy. I do think in the end that philosophy is not so much what you read; is how you read it. (When I approach a text in philosophy I simply want to know what it means, not what it means to me).

\section{LuCa CORTI \& DiAna COUTO: How has the debate on skepticism changed since the pub- lication of your 1992 book Unnatural Doubts?}

Michael WiLliams: I don't know exactly how much influence my book had. In the foreword to his book Epistemic Angst (2015), Duncan Pritchard says it is one of the most important books in epistemology - if not philosophy - for the last 50 years, but as far as I know he's the only person who thinks that. But it is still in print, so I suppose it must have some influence.

But the people settle into schools of thought. I call my view contextualism which I've now given up because that word has been taken over by this view attributed to contextualism - the sort of view that was developed by Stuart Cohen, Keith De Rose. David Lewis has a version of it. I'm not sympathetic to it because my notion of context was never that notion of context. That notion of context is really "conversational" or "dialectical context". Roughly speaking: you can change the standards of justification and focus on the standards for knowledge that are enforced by what error possibilities are brought up in the conversation. And in the end "context" is very much a matter of the question under discussion - what error possibilities need to be excluded by one's evidence or whatever, if one is to be knowledgeable. My notion of context was always multi-dimensional. I think in Problems of Knowledge I spelled that out: there are a number of factors that constitute context. And they are not just what's been talked about: it's not just what error possibilities are in play in the current conversation. First of all, there is background knowledge, there is standing objections that might be around to certain views that are put forward, but there is also one's actual worldly situation (in the case of perceptual knowledge). Being in a position to know is a matter of how you are fixed in the world, and not just what error possibilities are flitting through your mind.

This goes back to the question about theoretical diagnosis. I felt I could only be free to take that view of context, if I also had things to say in response to Barry Stroud's question about why there is something fishy about the question "How do I know anything whatsoever about the world?". In other words, I couldn't just dogmatically offer that rich view of context which 
I think is Austin espouses (I was a little unkind to Austin on Unnatural Doubts) as did Wittgenstein for that matter. But I couldn't just confront the more traditionally minded in epistemology with that notion of context. I also had to have the diagnostic story as to why there was something not quite right about the idea we can formulate a clear question just by saying "all I want to know is how you know anything whatsoever". But I did not want to just say that was meaningless. That had to be a story to say about how you would already have to be thinking to think that was a good question to ask. That's what I think is distinctive about my approach. You can't just confront the skeptic (even with this view of context), and just say "Oh well, you know, your question makes no sense if you take this view". Well that's true, but you'll have to have a story about why that isn't going to seem a very good response, or a complete response. In taking such stance, the book was not mainstream.

Currently, I'm writing about Wittgenstein and once more I'm out in left field by myself. The fashionable approach to Wittgenstein now is this so-called "Hinge Epistemology". The basic view of "Hinge Epistemology" is that there are these kinds of deep presuppositions that are the framework within which we justify, but they are themselves not properly thought of as items of knowledge. They have a special sui generis character. But as I pointed out in my talk here the other day, people are free to take that view, but they're not free to attribute it to Wittgenstein, for he states quite clearly that the hinges are things we know with mathematical certainty. So recently I've been working on the question "Is There a Line of Thought in Wittgenstein that Would Justify that View?". I think there is, and I think it's close to some of the thoughts Austin has in Sense and Sensibilia (1962). At the same time, I think that there are some things Wittgenstein has to say that are not clearly in Austin, and which need to be said. Such views work very well with some other lines I've taken in the past - which is again the lingering influence of Sellars - on why the justification or knowledge ascription has a "default and query" structure. (I once followed Brandon and called 'default' a challenge, but I've changed it because I actually think that not all questions are challenges; some of them are just explanatory questions so I had to generalize the notion). What makes it Sellarsian is this Sellars' famous remark, that McDowell loves, "in characterizing an episode or a state as that of knowing, we are not giving an empirical description of that episode or state; we are placing it in the logical space of reasons, of justifying and being able to justify what one says" (1956, pp. 298-299). So I called this "the default a challenge" a view about the deontic structure the space of reasons". This is something that is clear in my later writings and in my earlier writings, but I actually think epistemic concepts are a species of deontic concepts. They are about the right to assert or to use in inference. They are about rights and permissions about standings in the space of reasons. That's a deontic notion. But I think there are deep reasons why there have to be cases in which knowledge is the default position. It's not terribly deep; it's the thought that unless there are very simple matters in which you are reliably knowledgeable you couldn't really speak about the world at all. If just anything could be false at any time, you wouldn't get as far as having any beliefs much less than any knowledge. Wittgenstein is very clear about that in On Certainty, and that's what the "hinge epistemologists" miss. That's why hinges aren't just commitments. They are not just commitments. They have to be right. As he pointed out: you can't make a mistake in arithmetic unless you can add up, just as you can't have a bike accident until you've learned to ride. It happens that a lot of things have default and challenge structure (Only people who normally stay up can fall up.) There's a background 
of competence in any rational undertaking, such as inquiry, justification etc... There's an essential background of competence without which nothing you do could count as a mistake. I think that aspect is all over in On Certainty (Wittgenstein, 1969), and it's simply missed by the standard account of what Wittgenstein is doing. I think that, among the early commentators, Marie McGinn was really quite good at recognizing this aspect (I think she is eventually too generous to the skeptical argument. So in the end she's forced back into something like this hinge epistemology view that these things can't be knowledge). I think hinges can be knowledge, but not for being grounded, but rather by being manifestations of an essential basic competence, without which the notion of error would get no grip. That's what I'm trying to work out.

I decided that I shouldn't make it Wittgenstein's view, because these are just notes: this is a line of thought that he offers, but without final endorsement, because after all he was writing these notes up to a few days before he died. So the latest subtitle of my contribution is "Themes from Wittgenstein" (it might become "Themes from Austin and Wittgenstein"). It will be a development beyond Unnatural Doubt, that's for sure.

LuCa CORTI \& Diana Couto: Your work has focused on a variety of topics. In some philosophical debates, your name is associated with the position commonly labeled "contextualism". How would you explain the core thesis and philosophical value of the contextualist position? How would you differentiate your version from (and relate it to) other versions of contextualism?

MiChael WiLliams: As I said, my notion of context is multi-dimensional, whereas theirs is uni-dimensional. Theirs is "conversational context". In some papers I call their view "simple conversational contextualism", because I think it is a single-dimensional notion of context, whereas my notion of context really extends to situation. Whether it even makes sense to ask for reasons depends on who's asking: not just what is asked but who is asking, and who is asking whom, and in what wordly situation. That looks like externalism, but it isn't because it's not generalizable in the way externalism is. It's just that according to my position worldly situation is one dimension of context, but not the only one. That's the difference. If you look at Problems of Knowledge, you see I give five dimensions which are diagnostic. Context is a very complicated notion but, as I said, now I'm trying to replace "contextual" with "circumstance-dependent", so I now say that "knowledge is circumstance-dependent", which I think is a decent way of making the distinction I want to make.

LuCA CORTI \& DIANA COUTO: Do you think your work can have impacts in fields other than philosophy? How do you envisage such impact?

Michael WiLliams: There was a view that Rorty had, which I think might be right: concerning the impact of a work, philosophy is slow and works more by osmosis than by moments of epiphany. You don't just see the light - especially society doesn't just see the light. But I do think over time intellectual atmospheres could change. The economist Keynes famously said that even the most hard-headed practical men, though they don't realize it, are usually the 
slaves of some long dead economist. Perhaps the same is true of philosophy as well. People think that they are uninfluenced, but it just means they don't know where the influence came from. I don't expect to have that influence personally. I think perhaps I could just help to shift the Zeitgeist a little bit.

\section{LUCA CORTI \& DiAna COUTO: How would a Wittgensteinian orientation in epistemology (especially coming from On Certainty) bear on the epistemology of religious belief?}

Michael WiLliams: That is a very interesting question. Everyone knows that Wittgenstein's notes On Certainty were prompted by his discussions with Norman Malcolm - when he was visiting Malcolm in Ithaca, New York - towards the end of his life. They agreed to meet to discuss philosophy, but it wasn't going very well. So Malcolm suggested they make G. Moore's two papers "Proof of an External World" (1939) and "A Defense of Common Sense" (1925) the topic of that discussions. A lot of people who write about Wittgenstein think that Moore's papers are responses to skepticism - and this sort of hinge epistemology stuff gives you a kind of all-purpose response to skepticism with its various forms. But Moore's papers weren't responses to skepticism. This is historical. They were part of Moore's lifelong battle against idealism, and we have Moore's words for that, in his response to his critics (in the Philosophy of G.E. Moore (Moore, 1942)). I think that Wittgenstein did not see the papers as raising the same problems. He thinks that Cartesian skepticism - i.e. the external world problem - is just an illusion. For him there is no such thing as "not believing in the external world" or "doubting the existence of the external world". It does in the end collapse into a kind of incoherent position - but I do emphasize in the end, he doesn't think it's quick. But when it comes to common sense - this is where we get back towards religion, in relation to Moore's propositions of common sense - Wittgenstein thought that was a very different matter. Because simply overcoming the Cartesian doubt didn't leave you with a world picture. It located you in the world, but it left room for what we might call (and it has become fashionable to call) "deep disagreement". I actually think that some of the examples in the text indicate this. The question of what to have to think about religious belief is in the background. Very often it is not addressed directly, but think of the many examples Wittgenstein provides: there is Moore meeting the king brought up to believe the world began with him. There is the people who think they go to the moon. And there is also the case where Wittgenstein imagines Moore coming in and saying "I know that this is bread and I know that this is wine" and Wittgenstein writes "would Catholics contradict him" (and it's not that they don't know Moore's arguments).

I think the one lesson we have to take home from Wittgenstein is that there are limits to argument - where argument is anything like Moorean proof, that's to say: by routine deductive or inductive steps from an acknowledged shared evidential base. If you think coercive argument like that - let's call them proofs - the point is that there are limits to argument as proof. And that's not, so to say, an illusion to be overcome; that's a fact of life.

So does that mean then that some kind of relativism follows? The answer is: no. You are under no obligation and possibly not even in a position even to attempt (just because you can't in that way prove another person wrong) to think that that person's views aren't just as coherent as your own. Clearly it's within the realm of human possibility to take that view. But this raises 
very old questions that go back to the birth of philosophy, questions regarding the distinction between logic and rhetoric really. There are kinds of persuasive speech which are not proof, but which are not just manipulation either. I think very often that's what you have to look for.

I haven't applied it directly to religious belief, but I think we're living in a moment, where people live in information bubbles of various kinds and hear nothing but what they already believe repeated to them endlessly. I think it's quite clear that the way out of this is not proof. For proof is intrinsically confrontational: the unspoken message offering proof is "you are completely wrong that I'm going to force you to admit it". If that's the message you give from the very beginning, you're not going to succeed.

So an interesting question is: "Can one, so to speak, rationally persuade?". I think we need to understand that there must be something between coercive proof and mere manipulation. Plato kicks the sophist and poets out of the Republic because they only manipulate - and in philosophy only reason could reign. I think there are some cases where we just have to agree, but not all.

When I teach history of modern philosophy, I point out that one of the great differences between Descartes and the continental metaphysicians, on the on hand, and Locke on the other, is that the former really are metaphysicians. They want to know the ultimate nature of reality and the relation of the world to God. And they want to prove it by the exercise of pure reason. Locke's deep motive in the "Essay Concerning Human Understanding" is political. He says that we really have to recognize the limits of arguments of a certain kind, and if we could, then he says, perhaps we could live together in peace and charity. That seems a very reasonable aspiration to me. I'd like to think that I could contribute to it.

What you can argue for depends a lot on who's talking to whom and when and where. It is not a recipe. I think that's what a lot of people don't like in epistemology, they want a recipe for rationality. It's just there's no recipe for it in that way. There's no recipe for writing a good novel.

I think Americans particularly find this hard to believe because the shelves are always packed with books of recipes, with titles like "The Seven Secrets of Immensely Rich People" or "How to Write a Good Novel". I was always skeptical about these sorts of books. Well, if the person really knew "how to become rich" or "how to write a good novel", wouldn't he or she be writing a book like this? Nobody is that charitable. Jokes aside, sometimes epistemology sounds like that. It is like how to succeed in the stock market: buy low, sell high.

This is a topic I'd like to write a little more about. I think Wittgenstein is very attuned to that, and you can see it in On Certainty. On matters of deep disagreement you can't behave like G.E. Moore holding up his hands and saying here is one hand and here is another. If you think that's what you are going to do, you are going to make no more progress against your interlocutors than Moore made against the skeptic. You'll fail in both cases and you will fail spectacularly. 
Luca Corti \& Diana Couto: Philosophers are often seen as people who strenuously defend their views - people who are not very willing to change their mind. Is there any argument (or view) on which you changed your mind with respect to some positions you previously hold - in your published or unpublished work? Would you mind telling us what was wrong and how you came to realize it?

Michael Williams: That depends on what you mean by "change your mind". My views have evolved quite a lot from the time of my first book, Groundless Belief. For instance, I am much more critical of Sellars than I was before. Although he is the great critic of logical empiricism, nevertheless he is shaped by it too.

You're always affected by the people you criticize, whether you know it or not. First of all, my exposure to Sellars was always limited by Rorty, but I don't have a lot of sympathy with Sellars' idea of the clash between the scientific world picture and our ordinary human understanding. Perhaps one thing that I never quite acknowledged is that I think there has to be a certain priority of the ordinary human life world. If you want to call that "a metaphysical commitment", I think it's one I have. That commitment is something I would like to make more explicit at least. I think it goes with a kind of pragmatism. I don't know if that's changed, but it is an evolution from my previous views.

A big change was of course early in life: I was a kind of logical empiricist when I was a student of Ayer, and then I went to the other side of the force. I was a logical empiricist and then I went over to Rorty and Sellars. But you don't have any control over this. That's what you do in the end in philosophy: you can't help but you go where the argument as you see it takes you.

\section{References}

Austin, J. L. (1962). Sense and Sensibilia. Oxford: Oxford University Press.

Burnyeat, M. (1982). Idealism and Greek Philosophy. What Descartes Saw and Berkeley Missed. Royal Institute of Philosophy Lectures, 13, 19-50.

Heidegger, M. (1962). Being and Time (trans. by J. Macquarrie \& E. Robinson). Oxford: Basil Blackwell, 1962 (first published in 1927).

Moore, G. E. (1925). A Defense of Common Sense. In J. H. Muirhead (ed.), Contemporary British Philosophy (second series). London: George Allen \& Unwin.

Moore, G. E. (1939). Proof of an External World. Proceedings of the British Academy, 25, 273300.

Moore, G. E. (1942). Reply to My Critics. In Paul Arthur Schilpp (ed.), The Philosophy of G. E. Moore. The Library of Living Philosophers, Vol. 4 (pp. 535-677). Evanston: Northwestern University.

Pritchard, D. (2015). Epistemic Angst: Radical Skepticism Groundlessness of Our Believing. Princeton: Princeton University press.

Rorty, R. (1979). Philosophy and the Mirror of Nature. Princeton: Princeton University Press. 
Sellars, W. (1956). Empiricism and the Philosophy of Mind. In H. Feigl \& M. Scriven (eds.), Minnesota Studies in the Philosophy of Science, Vol. I (pp. 253-329). Minneapolis, MN: University of Minnesota Press.

Travis, C. (2008). Occasion Sensitivity: Selected Essays. Oxford: Oxford University Press.

Williams, M. (1977). Groundless Belief: An Essay on the Possibility of Epistemology. Princeton: Princeton University Press.

Williams, M. (1991). Unnatural Doubts. Princeton: Princeton University Press.

Williams, M. (2001). Problems of Knowledge: A Critical Introduction to Epistemology. Oxford: Oxford University Press.

Wittgenstein, L. (1969). On Certainty (G. E. M. Anscombe \& G. H. von Wright (eds.); trans. by D. Paul \& G. E. M. Anscombe). Oxford: Blackwell.

The editorial and publishing process of this publication has been financed by the Ministry of Science and Higher Education from the funds for the dissemination of research (DUN) within the framework of publishing activity, contract no. 711/P-DUN/2019, period of implementation: the years 2019-2020. 